\title{
ISOLATION OF ROTAVIRUSES FROM CALVES WITH ACUTE ENTERITIS AND THEIR CULTIVATION IN VITRO
}

\author{
R. DVOŘÁK, J. ŠTĚPÁNEK, I. PŠIKAL, J. FRANZ
}

Veterinary Research Institute, 62132 Brno

Received September 30, 1992

\begin{abstract}
Dvořák R., J. Štěpánek, I. Pšikal, J. Franz: Isolation of Rotaviruses from Calves with Acute Enteritis and Their Cultivation in vitro. Acta vet. Brno, 62, 1993: $71-77$.

Five bovine rotavirus strains were isolated in monolayers of MA-104 cell culture from faeces of 3-to 11-day-old calves suffering from gastroenteritis. Cytophatic effect, accompanied by the release of cells from the glass surface of cultivation flasks was observed from the 5th to the 6th passage. After the stabilization of the cytopathic effect, the highest virus concentration was observed in cell cultures that had been frozen 18-36 hrs after inoculation. Electron microscopy revealed particles with typical rotavirus morphology. Antigenic relationship of the isolates with the reference strain Lincoln was confirmed by ELISA. The isolates were classified as members of the serological group A by ELISA and immunofluorescence assay. The identity of the rotavirus isolates was also confirmed by electrophoresis in agarose gel. The assay confirmed that their genome consists of segmented viral RNA, which produced in the electric field migration patterns, electrophorogrammes, typical of rotaviruses. In 4 isolates the migration speed of the segments in the electric field was identical with that of the reference strain. A different electropherotype was identified in the remaining isolate.
\end{abstract}

Bovine rotavirus, diarrhoea, cell culture, isolation

Rotaviruses are at present considered as important causal agents of diarrheic infections in many domestic and wild ruminants, swine, monkey, horse, cat, dog, mouse, rabbit, poultry, fish, and also man (Wyatt et al. 1974; Flewett and Woode 1978; Fulton et al. 1981; Hoshino et al. 1981; Theil et al. 1985; Thouless et al. 1986; Korych 1987; Marshall 1990). They are found especially in newborn farm animals (neonatal diarrhoea) and children. Rotaviruses have been detected in various climatic zones, mostly in connection with an outbreak of gastrointestinal infections with various intensity of clinical manifestation, ranging from asymptomatic infection to severe, even lethal cases (Dea et al. 1985; Korych 1987; Ruuska and Vesikari 1990).

Causal relation of rotaviruses to gastroenteritis in newborn calves was first described by $\mathrm{Mebus}$ et al. (1969), who induced gastroenteritis in calves by peroral administration of bacteria-free filtrates of faeces from scouring animals. Reovirus-like agents were detected in the gut contents of infected calves (Fernelius et al. 1972). After a series of unsuccessful attempts, the virus was isolated and adapted to the growth in cultures of bovine embryonic kidney cells (Fernelius et al. 1972). The isolate was identified as bovine rotavirus, different from reovirus (Flewett and Woode 1978). The new information concerning the aetiology of scours was confirmed by several authors in the U.S.A. (Ekern et al. 1981), United Kingdom (Woode et al. 1974; McNulty et al. 1977) and other countries including Czechoslovakia (Scherrer et al. 1976; Marsolais et al. 1978; Wyn-Jones et al. 1978; Köves 1979; Śmíd et al. 1980; Castrucci. et al. 1983; Barboi et al. 1987). Most studies, however, focused on the methods of rotavirus demonstration in faeces of calves suffering from gastroenteritis (Rodger and Holmes 1979; Śmíd et al. 1980; Ekern et al. 1981). Early attempts to isolate rotaviruses in cell or organ cultures derived from various animal species were unsuccessful. Studies with established cell lines of various origins were carried out with the aim of selecting suitable ones for the growth of rotavirus strains 
and for the diagnosis of rotavirus infection (Bryden et al. 1977; Butchaiah et al. 1984). Good results were obtained by using the cell line MA-104, derived from Maccacus rhesus foetal kidney (Castrucci et al. 1983; Butchaiah et al. 1984; Thouless et al. 1986). The virulence increased after repeated passages in the gastrointestinal tract of sensitive animals and the following transfer of the obtained virus suspension to a suitable cell culture (Birch et al. 1983; Korych 1987).

More effective adsorption of virus particles on cell monolayers was obtained by a short low-speed centrifugation performed immediately after inoculation (Korych 1987). Positive effect on the culture was also obtained using the roller culture technique ( $\mathrm{McNulty}$ et al. 1977; Thouless et al. 1986). But most important finding was treatment of rotavirus suspension with proteases (trypsin is the most frequently used treatment) results in a marked increase of virus infectivity (Almeida et al. 1978; Babiuk and Mohammed 1978).

These findings facilitated the isolation of new rotavirus strains from clinical samples and their cultivation in vitro, which is necessary for further studies of rotaviral antigenic structure, serotype identification as well as for the development and improvement of diagnostic methods and immunoprophylactic measures. For this reason, our experiments were concentrated on isolation of bovine strains occurring in cattle herds in the Czech Republic, the investigation of their growth properties and optimal culture conditions.

\section{Materials and Methods}

\section{Cell cultures and media}

The established line of foetal monkey kidney cells MA-104 was grown in Eagle's minimum essential medium (MEM) containing $10 \%$ foetal calf serum.

\section{Reference virus \\ Reference strain Lincoln, obtained from the Collection of zoopathogenic microorganisms in the Veterinary Research Institute, Brno, was used in the experiments.}

\section{Faecal samples}

Samples of faeces were collected during 1989-1990 in rearing premises where frequent scours were recorded in up to 3-week-old calves. The samples were collected into plastic bottles, frozen on dry ice, transforted to the laboratory and stored at $-22^{\circ} \mathrm{C}$ until processing. Eleven faecal samples, in which rotaviruses were demonstrated to be present by electron microscopy and ELISA, were used for the isolation.

\section{Inoculum preparation}

Inoculum for cell cultures was prepared from approximately $20 \%$ suspension of faeces in PBS. The suspensions were centrifugated at $7,000 \mathrm{~g}$ for 20 minutes and supernatants were filtered through a $0.22 \mu \mathrm{m}$ Millipore filter. Infectivity of rotaviruses in virus suspensions was enhanced by the addition of trypsin to a final concentration of $10 \mu \mathrm{g}$ per $1 \mathrm{ml}$. The suspensions were incubated at $37^{\circ} \mathrm{C}$ for 30 minutes and then used as the inoculum.

\section{Isolation and adaptation of strains to cell cultures}

Complete monolayers of MA-104 cells grown in Mueller's flasks were washed 3 times with serum-free Eagle's medium and inoculated with $0.5 \mathrm{ml}$ of trypsin-treated virus suspension per flask. After 1 hour incubation at $37^{\circ} \mathrm{C}$ with an occasional pouring of the inoculum over the monolayer surface, $5 \mathrm{ml}$ of calf serum-free Eagle's maintenance medium, supplemented with trypsin to the final concentration $1 \mu \mathrm{g}$ per $1 \mathrm{ml}$ of medium, were pipetted into each flask. The cultures were incubated at $37^{\circ} \mathrm{C}$ until a distinct cytopathic effect became apparent. If no CPE was evident, the incubation proceeded for 7 days at least. Then the cultures were frozen and stored at $-22^{\circ} \mathrm{C}$.

\section{Enzymoimmunoanalysis (ELISA)}

The direct sandwich method was used. Aliquots of series of two-fold dilutions ranged from $1: 2$ to $1: 256$. After washing, the antirotavirus antibodies conjugated with peroxidase were added. The reaction was visualized by the addition of a substrate consisting of hydrogen peroxide and 5-aminosalicylic acid and measured spectrophotometrically at $492 \mathrm{~nm}$. The results were compared with those of positive and negative controls, which were included into each series of examinations.

\section{Electron microscopy}

Electron microscopic identification of rotavirus was done as described by $\zeta_{\mathrm{m} i} \mathbf{d}$ et al. (1980). Approx. $20 \%$ suspensions of samples in PBS were prepared and centrifugated at 7,000 $\mathrm{g}$ for $20 \mathrm{~min}$. A drop of each sample was used for negative staining with $2 \%$ phospho-tungstic acid and examined by electron microscope Tesla BS 513. 
Electrophoresis of viral RNA in agarose gel

Horizontal electrophoresis in agarose gel, as described by Chudzio et al. (1989) and Pšikal et al. (1991) was used for the demonstration of virus RNA. The gel was prepared as a 5-mm-thick layer of $1.5 \%$ agarose boiled in $0.09 \mathrm{M}$ Tris-borate buffer, $\mathrm{pH}$ 8.2. The liquid gel was poured into a $8.5 \times 8 \mathrm{~cm}$ mould, into which a comb had been placed to form starts. After solidification, the mould was put into an electrophoretic vessel and poured over with Tris-borate buffer. The processed samples were put onto starts by a micropipette and after connection to a direct current generator, the electrophoresis was left to run at $100 \mathrm{~V}$ for $2 \mathrm{hrs}$. After switching off, the gel was stained in ethidium bromide solution $(1 \mu \mathrm{g} / \mathrm{ml})$ for $10 \mathrm{~min}$. The stained segments of RNA were viewed under ultraviolet light at $312 \mathrm{~nm}$.

Immunofluorescence test

Monolayers of MA-104 cells, grown on slides $0.8 \times 3.0 \mathrm{~cm}$ were washed to remove the growth medium, placed into polystyrene Petri dishes (diameter $6.0 \mathrm{~cm}$ ), inoculated with $0.5 \mathrm{ml}$ of examined virus and poured over with Eagle's maintenance medium. After $24 \mathrm{hrs}$ incubation at $37^{\circ} \mathrm{C}$ in an atmosphere containing $5 \% \mathrm{CO}_{2}$, the slides with monolayers were washed in PBS, fixed with chilled acetone $\left(-22^{\circ} \mathrm{C}\right)$ and dried at laboratory temperature. The monolayers were then stained with the direct conjugate to bovine rotavirus for $\mathbf{4 5} \mathrm{min}$. After washing in PBS, slides were mounted into glycerol solution in PBS and viewed under a fluorescence microscope.

Evaluation of virus growth in cell cultures

Cell cultures MA-104 grown in Mueller's flasks were inoculated with the same quantity of rotavirus $24 \mathrm{hrs}$ after the seeding. ELISA was used for the detection of virus concentrations in. the samples obtained by freezing of the cell cultures in different periods following inoculation.

\section{Results}

Virus isolation in cell cultures and characterization of cytopathic: lesions

No cytopathic changes were observed in any of the isolates in the 1st passage after 7 days of incubation. The first evident cytopathic changes developed in the 2nd or 3rd passage. They were noticed in cell cultures infected with five faecal samples (BR 14, BR 197, BR 207, BR 224 and BR 256) and were characterized by the formation of rounded cells on the surface of almost intact monolayers. In the 4th passage, the cytopathic lesions were already observed on 3rd day p. i. The number of degenerated cells, located on the surface of monolayer, or released into the medium, grew, and the first signs of impaired compactness of the cell layer became evident. CPE stabilized during the subsequent passages, corresponding to that of the reference strain Lincoln as for its dynamics and morphology. The first signs of cell degeneration appeared 18 to 24 hours after inoculation. The number of degenerated cells grew rapidly, and the proceeding destruction of the cell layer resulted in the release of cells from the glass surface (Plate XVIII.,. Fig. 3). CPE culminated 36 hours p. i. when 80 to 90 percent of the monolayer was destroyed. No CPE was observed during 3 passages in cell cultures inoculated with any of the remaining six samples.

Immunofluorescent investigations of the isolated strains

Although fluorescence was already recorded in the first two passages of 9 rotavirus suspensions, it was limited to single cells disseminated irregularly in the monolayer. Groups of cells, showing mostly granular, perinuclear fluorescence were observed in the 3rd passage in those cell cultures, from which cytopathogenic rotavirus strains were isolated. The first positive cells appeared 18 to 24 hours p. i. Fluorescence in approx. $5 \%$ of the cells was already detectable 6 hours. p. i. from the 4 th passage on. The number of cells grew rapidly and 20 to $25 \%$ of cells were positive 12 to 18 hours p. i. The fluorescence was located in the cyto- 
plasm and became diffuse. 40 to $50 \%$ of cells were positive 18 to 36 hours p.i. (Fig. 4). A similar type and extent of fluorescence was observed in cell cultures inoculated with the reference strain Lincoln.

Virus multiplication in cell cultures

As confirmed by ELISA, the rise of rotavirus concentration in inoculated cell cultures was proportional to the development of CPE and fluorescence. The first new virus was already detectable 6 hours p.i. and peak concentrations were reached 18 to 36 hours p. i.

\section{Electron and immunoelectron microscopy}

Virus particles, corresponding in morphology to rotaviruses, were seen in negatively stained preparations of the 5th passage of the cytopathogenic isolates (Fig. 5). The particles were aggregated into immune complexes by antibodies to the strain Lincoln. No other virus particles were observed in the preparations.

\section{Agarose gel electrophoresis of viral RNA}

Segments of RNA, belonging to four classes relative to their migration properties, were obtained by agarose gel electrophoresis of nucleic acid of the isolated rotavirus strains. The migration patterns were characteristic for rotaviruses. They can be used for direct species identification, and analysis of migration properties of certain segments enables to distinguish various electrophoretic types of the virus. As can be seen in Fig. 2, four of the isolates which yielded electrophorogrammes were identical with that of the strain Lincoln. A markedly different position of the segment 11, located between the segment 6 and the segment triad $7,8,9$, was evident in the electrophorogramme of the strain BR 207. A similar arrangement was found in the rotavirus strain present in the sample BR 125 which failed to adapt to cell cultures. The segment 11 was located between the segment 6 and segment triad 7,8,9, but in close vicinity of the segment 7 (Fig. 1). The two electropherotypes, different from the strain Lincoln, could be distinguished despite the limited resolution capacity of agarose gel, which did not allow a complete separation of all 11 segments. The segments 2 and 3 migrated together producing one broader and brighter band under UV light. Also the segments 7, 8 and 9 migrated together and thus the number of bands, visible under UV light, was reduced from 11 to 8 (Pšikal et al. 1991). No genome reassortment was observed in any of the isolates during the passages in cell cultures, as demonstrated by the comparison of electrophorogrammes of the final passages with genomic profiles of rotavirus strains present in the faecal samples.

\section{Discussion}

Isolation of bovine rotaviruses from faeces of calves affected with acute gastroenteritis, and their propagation in cell cultures are described. Faecal samples, in which high concentrations of rotaviruses had been confirmed by several methods, were used in isolation attempts. The samples were collected in several farms, and the rotaviruses present in them belonged to three different electropherotypes.

The cell line MA-104 which is used for the propagation of rotaviruses most frequently, was selected for the isolation attempts. Only 5 of the 11 rotavirus suspensions were adapted to cell cultures and could be passaged in vitro serially. This poor isolation success was apparently due to the fact that not all effective culture methods (roller cultures, e. g.) were applied. 
The typical cytopathic effect became stabilized in higher passages only and therefore the propagation of rotaviruses was checked by the fluorescent antibody technique. This technique is reliable enough and can be used for that purpose in virus strains propagating without characteristic CPE (Birch et al. 1983). Some authors reported the appearance of fluorescence 2 to 8 hours after inoculation, i. e. at the time when no CPE is detectable in infected monolayers. In our experiments, specific fluorescence became visible 6 hours after inoculation. No specific fluorescence was detectable in the 2 nd and $3 \mathrm{rd}$ subsequent passages of the rotavirus suspensions which failed to adapt to the growth in vitro.

Electron microscopic examinations of five cytopathogenic isolates demonstrated the presence of virus particles corresponding morphologically to either the oneor two layer capsid type of rotavirus. Immunoelectron microscopy confirmed the results of fluorescent antibody technique and ELISA, classifying all isolated strains as members of the serological group $\mathrm{A}$ as defined by Estes and Cohen (1989).

Genomic analysis by agarose gel electrophoresis of RNA allowed a further differentiation of the isolated strains. While the migration patterns of four of them were identical with that of the strain Lincoln, the fifth - BR 207 - belonged to another electropherotype, different from them in the position of segment 11. Passaging of isolated strains was not associated with any changes of their migration profiles.

Our results have confirmed the finding of Pšikal et al. (1991), that rotaviruses circulating in the local cattle population cannot be regarded as an entirely homogeneous set of strains. This finding should be considered in the ongoing updating of diagnostic methods and development of biological products for prophylactic application.

\section{Izolace rotavirů $\mathrm{z}$ telat $\mathrm{s}$ akutní enteritidou a jejich kultivace in vitro}

$\mathrm{Z}$ faeces 3-11denních telat nemocných gastroenteritidou bylo $\mathrm{v}$ monolayrech buněčné kultury MA-104 izolováno 5 kmenů bovinního rotaviru. Od 5.-6. pasáže byl jejich růst doprovázen rozvojem zřetelných cytopatických změn, spojejených s odpadáváním buněk od povrchu skla. Po stabilizaci cytopatického efektu, tj. od 5.-6. pasáže byla nejvyšší koncentrace viru zjištována v buněčných kulturách zmrazených $18-36$ hod. po inokulaci. Elektronovou mikroskopii bylo prokázáno, že morfologie izolovaných kmenů odpovídá tvarem i velikostí rotaviru. Imunoenzymatickým testem ELISA byla potvrzena antigenní příbuznost izolátů $\mathrm{s}$ referenčním kmenem Lincoln. Výsledky ELISA testu a imunofluorescenčního testu preferují zařazení izolovaných kmenů do séroskupiny $\mathrm{A}$. Identita izolátů $\mathrm{s}$ rotaviry byla dále potvrzena $\mathrm{i}$ elektroforézou $\mathrm{v}$ agarózovém gelu. Tímto testem bylo potvrzeno, že jejich genom sestává ze segmentů virové RNA, které v elektrickém poli vytvořily pro rotaviry charakteristické migrační vzorce-elektroforetogramy. Migrační aktivita těchto segmentů byla u 4 izolovaných kmenů identická $\mathrm{s}$ migrační aktivitou referenčního kmene. Jeden $\mathrm{z}$ izolátů byl elektroferotypově odlišný. 


\section{Выделение ротавирусов из телят с острым гастроэнтеритом и их күпьтивирование ин витро}

Из пометов 3-11 денных телят заболеваемых гастроэнтеритом выделили в монослоях клеточной күльтүры МА-104 пять штаммов бычьего ротавируса. Их рост провожало от 6-ого пассажа развитие отчетливых цитопатических изменений, соединенных с отпаданием клеток от поверхности стекла. После стабилизации цитопатическохо еффекта, т. е. от 5-6-ого пассажа обнаружили самую большую концентрацию вируса в клеточных культурах замороженых 18-36 часов после инфицирования. Помощью электронного микроскопа доказали что морфология выделенных штаммов сходится формой и размером с ротавирусом. Иммуноферментный анализ (ЕЛИСА) подтвердил антигенное родство выделений с эталонным штаммом Линколн. Результаты иммүноферментного анализа и иммунофлуоресцентного анализа предпочитают отношение выделенных штаммов в серогруппе А. Идентичность выделений с ротавирусами 'тоже подтвержена электрофорезом в агарозовом геле. Этот анализ подтвердил, что их геном состоит из сегментов вирусной РНА, которые образовали в электрическом поле миграционные формулы - электрофоретограммы - типичные для ротавирусов. Миграционная активность этих сегментов в электрическом поле была у четырех выделенных штаммов идентичная с миграционной активностью эталонного штамма. Один из выделенных штаммов отличался электрофоретипово.

\section{Acknowledgements}

The authors wish to thank to Dr. Lubomir Valicek for electron microscopy of rotaviral particle and Mrs. Irena Trnečková for the careful photographic documentation of the results.

\section{References}

ALMEIDA, J. D. - HALL, T. -BANATVALA, J. E. - TOTTERDELL, B. M. - CHRYSTIE, I. L.: The effect of trypsin on the growth of rotavirus. J. Gen. Virol., 40, 1978: 213-218 BABIUK, L. A. - MOHAMMED, K. A.: Trypsin and bovine rotavirus replication. Vet. Rec., 102, 1978: $61-62$

BARBOI, G. -CARSTET, I.-CRIVULESCU, P.-STAICU, L.-MARIN, D.: Isolation of cytopathogenic bovine rotavirus strain in the Socialist Republic of Romania. Arch. Exper. Vet. Med., 41, 1987: $926-929$

BIRCH, C. J.-RODGER, S. M. -MARSHALL, J. A.-GUST, I. D.: Replication of human rotavirus in cell culture. J. Med. Virol., 11, 1983: 241-250

BRYDEN, A. S.-DAVIES, H. A.-THOULESS, M. E.-FLEWETT, T. H.: Diagnosis of rotavirus infection by cell culture. J. Med. Microbiol., 10, 1977: 121-125

BUTCHAIAH, G.-BOTNER, A. G.-LUND, E.: Studies on the growth of bovine rotavirus in cell cultures. Zbl. Vet. Med. B, 31, 1984: 760-769

CASTRUCCI, G.-FERRARI, M.-FRIGERI, F.-CILLI, V.-DONELLI, G.-ANGELILLO, G.-BRUGGI, M.: A study of cytopathic rotavirus strains isolated from calves with acute enteritis. Comp. Immun. Microbiol. Infect. Dis., 6, 1983: 253-264

DEA, S. - BEGIN, M. E.-ARCHAMBAULT, D.-ELAZHARY, M. A. S. Y.-ROY, R., S.: Distinct rotavirus isolated from asymptomatic calves. Cornell Vet., 75, 1985: 307-318

EKERN, L. J. - SCHIPPER, I. A.-McMAHON, K. J.: Neonatal bovine enteritis: detection of rotavirus by counterimmunoelectrophoresis and enzyme-linked immunosorbent assay. Can. J. Comp. Med., 45, 1981: 135-139

ESTES, M. K.-COHEN, J.: Rotavirus gene structure and function. Microbiol. Rev., 53, 1989: 410-449 
FERNELIUS, A. L.-RITCHIE, A. E.-CLASSICK, L. G.-NORMAN, L. O.-MEBUS C. A.: Cell culture adaptation and propagation of reovirus-like agent of calf diarrhoea from a field outbreak in Nebraska. Arch. Ges Virusforsch., 37, 1972: 114-116

FLEWETT, T. H. - WOODE, G. N.: The rotaviruses. Arch. Virol., 57, 1978: 1-23

FULTON, R. W.-JOHNSON, C. A. -PEARSON, N. J.-WOODE, G. N.: Isolation of a rotavirus from a newborn dog with diarrhea. Am. J. Vet. Res., 42, 1981: 841-843

HOSHINO, Y.-BALDWIN, C. A.-SCOTT, F. W.: Isolation and characterization of feline rotavirus. J. Gen. Virol., 54, 1981: 313-323

CHUDZIO, T.-KASATYIA, S.-IRVINE, N.-SANKAR-MISTRY, P.: Rapid screening test for the diagnosis of rotavirus infection. J. Clin. Microbiol., 27, 1989: 2 394-2 396

KORYCH, B.: Laboratorní diagnostika virových gastrointestinálních onemocnění. Avicenum, $1987,80 \mathrm{p}$.

KÖVES, B.: Isolation of cytopathogenic rotavirus from neonatal calves. Acta Microbiol. Acad. Sci. Hungar., 26, 1979: 225-231

MARSHALL, S. H. -SAMAL, S. K.-McPHILLIPS, T. H.-MOORE, A. R. -HETRICK, F. M.: Isolation of a rotavirus from smelt, Osmerus mordax (Mitchel). Journal of Fish Diseases, 13, 1990: 87-91

MARSOLAIS, G.-ASSAF, R.-MONTPETIT, C.-MAROIS, P.: Diagnosis of viral agents, associated with neonatal calf diarrhea. Can. J. Comp. Med., 42, 1978: 168-171

McNULTY, M. S.-ALLAN, G. M.-McFERRAN, J. B.: Cell culture studies with a cytopathic bovine rotavirus. Arch. Virol., 54, 1977: 201-209

MEBUS, C. A. - UNDERDAHL, N. R.-RHODES, M. B. - TWIEHAUS, M. J.: Calf diarrhea (scours) reproduced with a virus from field outbreak. Univ. Nebr. Res. Bull. Exp. Station, 233, 1969: $1-16$

PŚIKAL, I.-DVOŘAK, R.-FRANZ, J.-ŠTĚPÁNEK, J.: Rapid identification of bovine rotavirus by electrophoresis in agarose gel. Acta vet. Brno, 60, 1991: 253-261

RODGER, S. M. - HOLMES, I. H.: Comparison of the genomes of simian, bovine, and human rotaviruses by gel electrophoresis and detection of genomic variation among bovine isolates. J. Virol., 30, 1979: 839-846.

RUUSKA, T.-VESIKARI, T.: Rotavirus disease in finnish children: use of numerical scores for clinical severity of diarrhoeal episodes. Scand. J. Infect. Dis., 22, 1990: 259-267

SCHERRER, R. - COHEN, J. - L'HARIDON, R. - FEYNEROL, C. - FAYET, J. - C. : Reovirus-like agent (rotavirus) associated with neonatal calf gastroenteritis in France. Ann. Rech. Vétér., 7, 1976: 25-31

SMIID, B. - VALÍCEKK, L. - MENSÍK, J. - ŠTĚPÁNEK, J.: Rychlá elektronově mikroskopická diagnostika rotavirových průjmů telat a selat. Veterinářství, 30, 1980: 399-401

THEIL, K. W.-REYNOLDS, D. L.-SAIF, Y. M.: Isolation and serial propagation of turkey rotaviruses in a fetal rhesus monkey kidney (MA-104) cell line. Avian Dis., 30, 1985: 93-104

THOULESS, M. E.-DiGIACOMO, R. F.-NEUMAN, D. S.: Isolation of two lapine rotaviruses: characterization of their subgroup, serotype and RNA electrotypes. Arch. Virol., 89, 1986: $161-170$

WOODE, G. N.-BRIDGER, J. C.-HALL, C.-DENNIS, M. J.: The isolation of a reovirus-like agent associated with diarrhoea in colostrum deprived calves in Great Britain. Res. Vet. Sci., 16, 1974: 102-105

WYATT, R. G.-KAPIKIAN, A. Z.-THORNHILL, T. S.-SERENO, M. M.-KIM, H. W.-CHANOCK, R. M.: In vitro cultivation in human fetal intestinal organ culture of reovirus-like agent associated with nonbacterial gastroenteritis in infants and children. J. Infect. Dis., 130, 1974: $523-528$

WYN-JONES, A. P. - FRENZEL, B. - HÄRTNER, D.: Isolation of rotavirus from calves in the Federal Republic of Germany. Zbl. Vet. Med. B, 25, 1978: 168-170 
Dvořák R. et al.: Isolation of... pp. 71-77

Plate XVII.

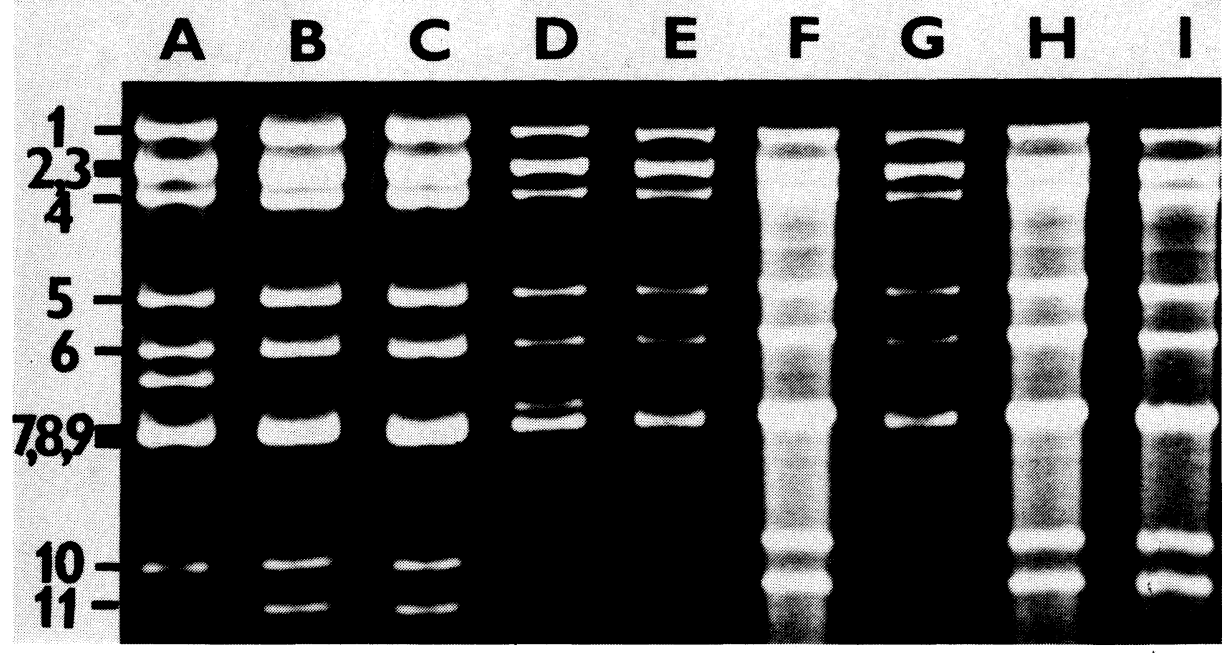

Fig. 1: Electrophoresis of rotavirus RNA extracted from diarrhoeic calves in 1,5\% agarose gel stained with ethidium-bromide. Lanes: A - BR 207, B - BR 197, C - BR 237, D - Br 125, E - BR 198, F - BR 224, G - BR 144, H - BR 256, I - BR 14.

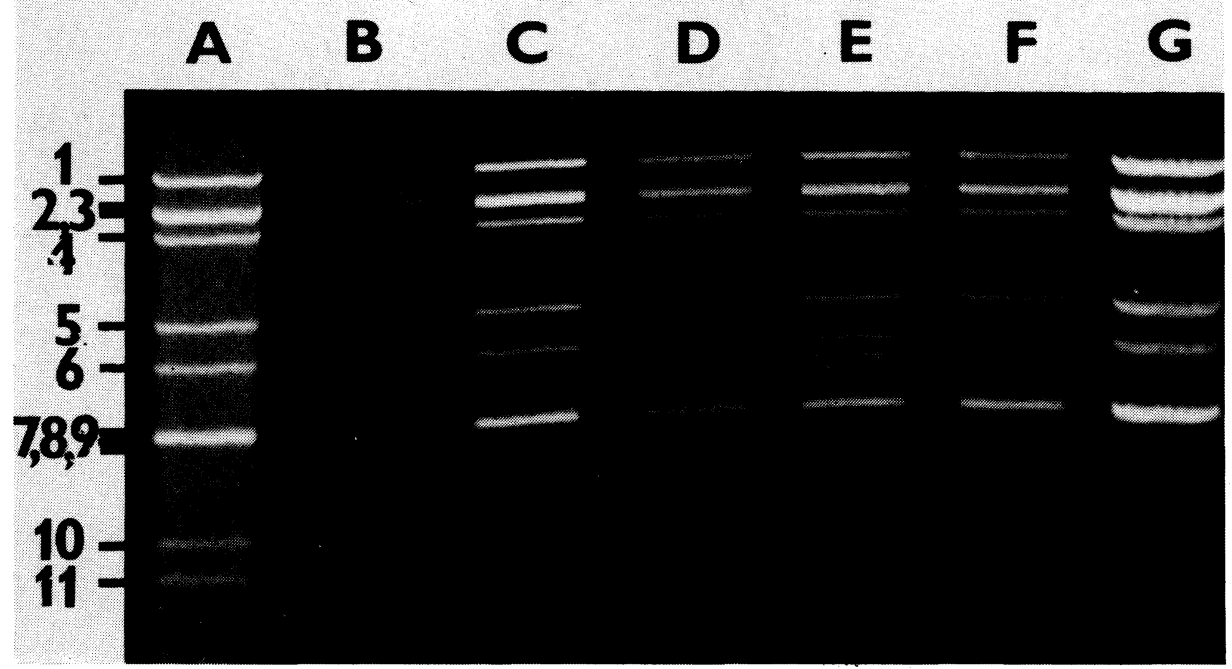

Fig. 2: Electrophoresis of RNA extracted from rotavirus strain grown in cell culture MA - 104. Lanes: A - rotavirus-positive faecal sample (internal laboratory standard), B - BR 14, C - BR 197, D - BR 224, E - BR 207, F - strain Lincoln, G - BR 256. 

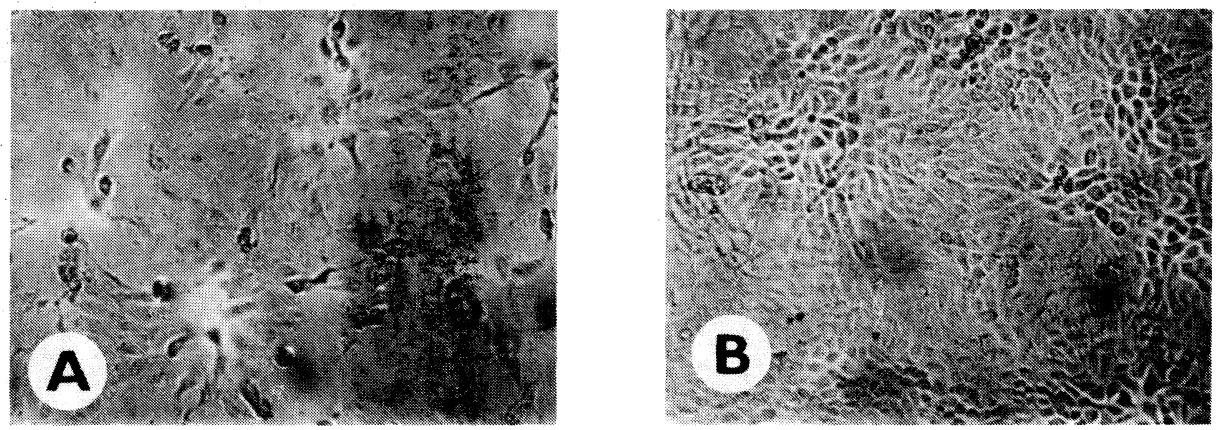

Fig. 3: Cythopathic effect induced by rotavirus strain BR 207 at the fifth passage in MA - 104 cells. A: 24 hours post inoculation, B: uninfected control culture.
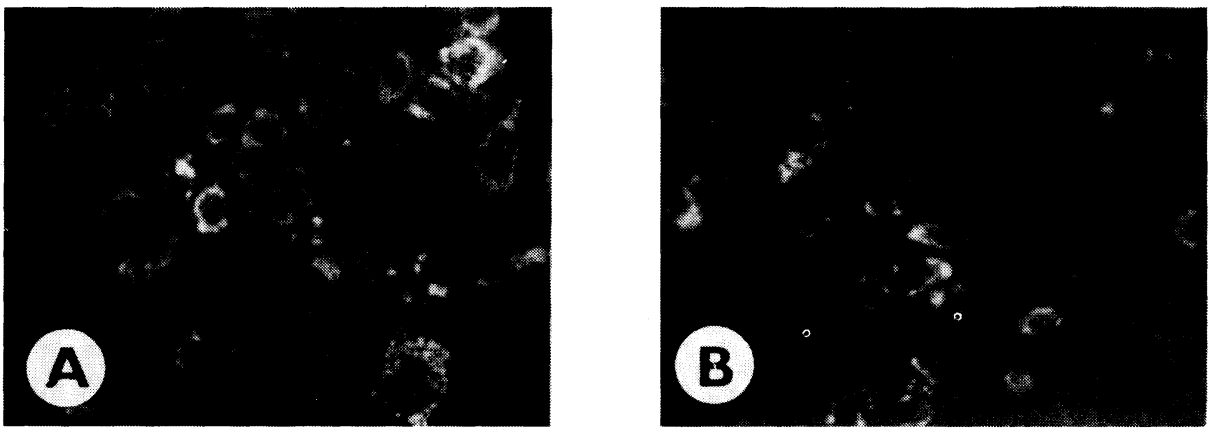

Fig. 4: Specific immunofluorescence in the cytoplasm of MA - 104 cells. A: strain BR 207, B: strain BR 224.

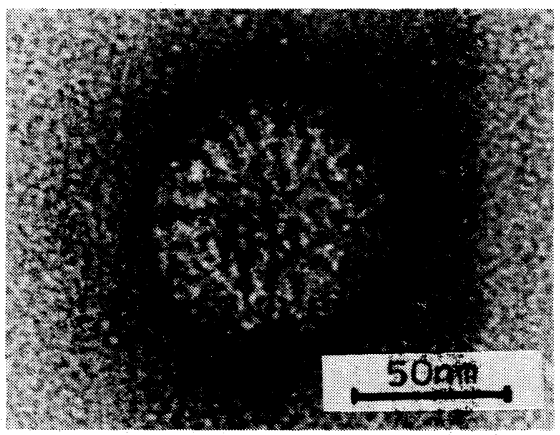

Fig. 5: Viral particle of isolated rotavirus strain BR 207 (negative staining). 